\title{
Teacher Pedagogic Competencies in the Perspective of Students
}

\author{
(Based on the 2019 parent-teacher support questionnaire, AKSI 2019)
}

\author{
Suci Paramitha Liestari*, Muhardis \\ Pusat Asesmen dan Pembelajaran, Balitbang dan Perbukuan \\ Kemendikbud \\ Jakarta, Indonesia \\ *suci.paramitha@kemdikbud.go.id,muhardis@kemdikbud.go.id
}

\begin{abstract}
The results of the 2015 to 2017 UKG (Teacher Competency Test) are not much different from the measurements carried out in 2018. Teachers' UKG scores are still below 75. The purpose of this study is to describe teacher competencies that are still weak based on the results of the 2019 AKSI (Indonesian Student Competency Assessment) questionnaire's Parent Teacher Support. The questionnaire contains six aspects of pedagogical competence, namely: understanding student characteristics, applying various approaches, strategies and methods, determining learning objectives, understanding communication strategies, using information on assessment results, and reflecting on learning. The method used is a qualitative descriptive method. The results found that students stated that most of the teachers $(50 \%-60 \%)$ had good pedagogical competence. This means that there are still $40 \%$ of teachers who have not mastered their pedagogical competence. Teachers are still weak in terms of pedagogical competence, for example the ability to innovate in designing and implementing learning using model learning, tends to teach with monotonous methods, and lacks the knowledge to do reflective.
\end{abstract}

Keywords-teacher competency test, pedagogical competence, AKSI 2019, parent teacher support

\section{INTRODUCTION}

AKSI or Indonesian student competency assessment [1] is a program for mapping educational outcomes to monitor the quality of education at a national / regional that describes the achievement of student abilities through surveys. The AKSI result data is expected to be the basis for the formulation of policies and programs to improve the quality of learning in particular and the quality of education in general.

Some of the objectives of implementing AKSI are a) achievement, namely knowing and comparing the success rate of educational programs, b) diagnosis, namely diagnosing student strengths and weaknesses in terms of cognitive and background, c) quality improvement, namely identifying factors that affect student achievement, d) monitoring the progress of the program's success periodically and systemically
The sample in this survey was class IX students from junior high schools in all provinces in Indonesia, a maximum of 50 students per school. The sampling technique used is Multistage Probability Sampling. The first stage select sample districts / cities, the second stage select sample schools, and the third stage select sample students The sample received a cognitive test (for math, reading, and science test material) and filled out a questionnaire.

Survey results for 2019 [2] shows that for reading competence, less $(55.85 \%)$ find and retrieve explicit information contained in discourse; make a simple interpretation of a text; Medium (38.01\%) able to make interpretations from implicit information in the text; able to make conclusions from the integration of several information in a text; and Good (6.14\%) able to integrate some information across texts; evaluate the content, quality, way of writing a text; be reflective of the content of the text.

For math competence, Less (79.44\%) have basic math skills: basic computing in the form of direct equations, basic concepts related to geometry and statistics, and solving simple routine math problems; Medium (18.98\%) Able to apply their mathematical knowledge in more diverse contexts; Good $(1.58 \%)$ Able to reason to solve complex and non-routine problems based on their mathematical concepts.

Meanwhile, for science competence, less $(66.11 \%)$ have basic knowledge related to biology, physics, chemistry and earth sciences; Medium (32.12\%) able to apply knowledge of biology, physics, chemistry and earth sciences in various contexts; Good (1.78\%) able to apply and communicate scientific concepts to solve non-routine problems, both in practical and research / experimental situations

Based on the survey results, it is known that our students are already good at basic skills but need assistance for analysis and reasoning's skills. This needs to be a reminder for teachers that the survey results are an effort to determine the professional level of teachers in learning [3]. The part that plays an important role here is pedagogical competence. The 
study conducted by Keller et al. [4] revealed that teacher pedagogical content knowledge positively predicted students' achievement, neither did teacher pedagogical content knowledge predict students' interest, nor teacher motivation students' achievement

From the survey results, it can be assumed that teachers are still weak in their pedagogical competence. In fact, pedagogy is one of the four main competencies of teachers [5]. Previously, research was conducted by Utiarahman [6] and Santosa [7] also found something similar. Teachers are still weak in organizing quality learning as evidenced by the fact that teachers have not fully involved the potential, both students's physical and nonphysical. Other research [8], found that teachers are still weak in the accuracy in choosing learning contexts, namely learning activities, indicators and basic competencies related to real life students.

The following article will describe the perspective of Indonesian students based on the student questionnaire "Parent Teacher Support". The teacher pedagogical competencies that were asked in the questionnaire included the following:

- Understand student characteristics related to physical, intellectual, socio-emotional, moral, spiritual, and socio-cultural backgrounds. (1.1)

- Apply various approaches, strategies, methods, and learning techniques that educate creatively in the subject being taught. (1.2)

- Determine the learning objectives being taught. (3.2)

- Using information on the results of assessment and evaluation to determine learning completeness (9.1)

- Reflecting on the learning that has been implemented. (10.1)

\section{METHODS}

\section{A. Sample}

This study uses AKSI survey data in 2019 for $8^{\text {th }}$ grade junior high school students. The samples were determined using a multi-stage probability sampling. The first stage select sample districts / cities, the second stage select sample schools, and the third stage select sample students. The sample used in this study consisted of 17,099 students . This data was obtained from the Center for Assessment and Learning, the Ministry of Education and Culture.

\section{B. Instrument}

The instruments used in AKSI survey were cognitive instruments (mathematics, science, and reading) and questionnaire instruments. The AKSI Survey questionnaire instrument consisted of a questionnaire for school principals, teachers, and students. (https://pusmenjar.kemdikbud.go.id/aksi-2/). This study uses student questionnaire namely parent teacher support and cognitive score (mathematics, science, and reading).

\section{Data analysis}

The purpose of this study is to describe teacher competencies that are still weak based on the results of the 2019 AKSI (Indonesian Student Competency Assessment) questionnaire's Parent Teacher Support. The method used is a qualitative descriptive method

\section{RESULTS}

A. Understand the characteristics of students related to physical, intellectual, socioemotional, moral, spiritual, and socio-cultural backgrounds.

- In terms of the convenience of students interacting with the teacher, how often do you do the following things?

When I look gloomy, the teacher pays attention to us

(42.93\% sometimes, $21.26 \%$ often)

Learning with teachers in school is fun.

(57.66\% often, $2.5 \%$ rarely)

Only $21.26 \%$ of teachers who often pay attention to students, but, another fact is that as many as $57.66 \%$ of students still stated that learning with teachers at school is fun.

- In terms of the teacher's respect for students, how often does this happen in your classroom?

Most of the teachers at school really appreciate me. ( $58.87 \%$ often, $8.65 \%$ rarely)

Most of the teachers are friendly to me.

(59.35\% often, $6.25 \%$ rarely)

Most of the teachers were late to class.

(12.72\% often, $52.3 \%$ rarely)

Most of the teachers were absent.

(13.69\% often, $53.51 \%$ rarely)

Most of the teachers play on the computer or smartphone jh'while they are in class.

( $14.73 \%$ often, $50.49 \%$ rarely)

Most teachers receive telephone calls while teaching.

(50.07\% often $14.01 \%$ rarely)

From the student's answer distribution, we can conclude that most teachers (about 50\%) can respect the students, be friendly to students. 
B. Implementing various approaches, strategies, methods, and learning techniques that educate creatively in the subject being taught.

- Solve problems and think creatively

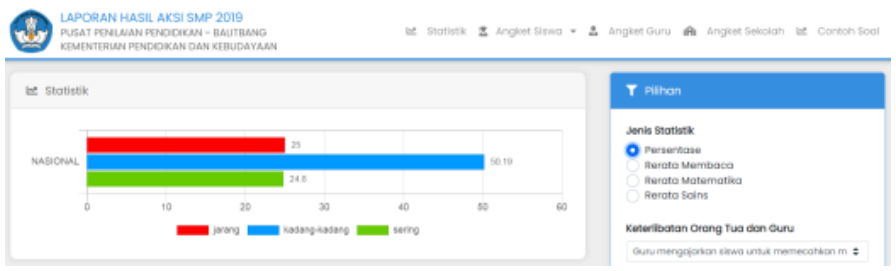

Fig. 1. Percentage of teacher solving problems and thinking creatively

From figure 1, it is known that $50.19 \%$ of students answered that their teacher "sometimes" teaches them to solve problems and think creatively.

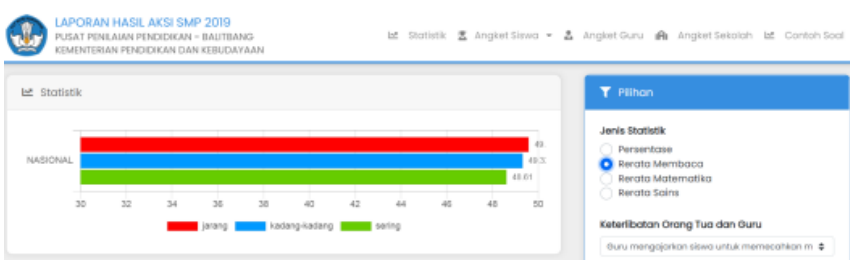

Fig. 2. Student's national reading mean score for solve problems and think creatively

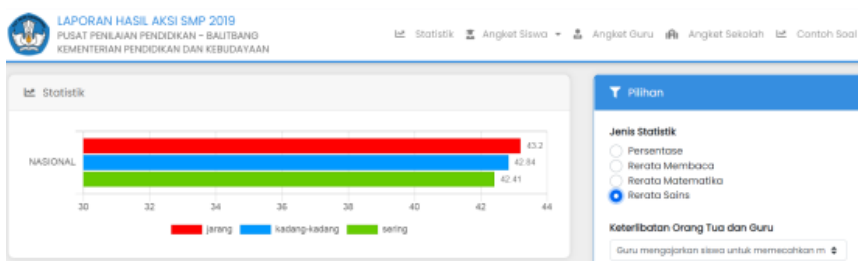

Fig. 3. Student's national science mean score for solve problems and think creatively.

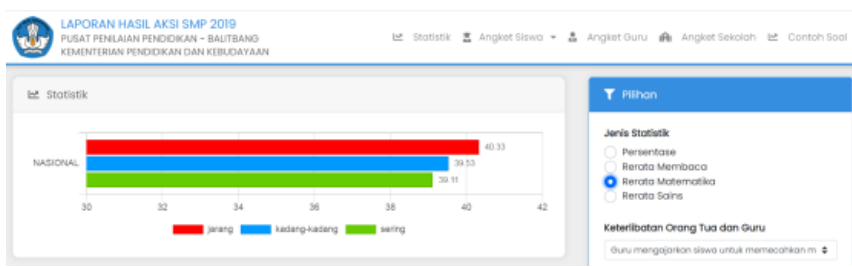

Fig. 4. Student's national mathematics mean score for solve problem and think creatively.

From the three figure (figure 2-4), we get the information that the mean score of mathematics, reading and science for students who answered their teacher "sometimes" taught them to solve problems and think creatively was lower than those who answered "rarely".

- With regards to how teachers teach students to solve problems and think creatively, how often do things like this happen in your classroom?
Most teachers require students to make different solutions to a problem in the task.

(60.16\% often, $6.86 \%$ rarely)

Most teachers are very concerned about ensuring that no student's work is duplicated by other students' work.

\section{(54.48\% often, $7.65 \%$ rarely)}

Most teachers encourage students to be open to new ideas.

(64.31\% often, $5.01 \%$ rarely)

Students are given the opportunity to express their ideas and thoughts.

(61.37\% often, $6.29 \%$ rarely)

Most teachers do not encourage their students to think independently.

(40.46\% often, $13.64 \%$ sometimes)

In the view of students, more than $50 \%$ teacher often requires students to think creatively, to be open to new idead, to express ideas and thought, and encourage students to think independently.

- How often do teachers encourage you to do the following?

Discuss how to solve a problem

( $44.24 \%$ often, $9.04 \%$ rarely)

Defend answers with evidence.

(47.06\% often, $6.44 \% \mathrm{~min}$ )

Group discussion.

(35.14\% often, $3.3 \%$ rarely)

Not easily give up.

(49.78\% often, $5.71 \%$ rarely)

Check the accuracy of the information obtained.

(42.46\% often, $6.47 \%$ rarely)

Correct errors from tasks that have been done.

(38.83\% sometimes, $5.25 \%$ rarely,)

We can see that students' answers vary quite a bit to that question and we can conclude that less than $50 \%$ of teacher can encourage the students with the following item, especially for correct error from the task that have been done and group discussion.

C. Determine the learning objectives being taught.

- Integrate values in lessons with everyday life 
(1)

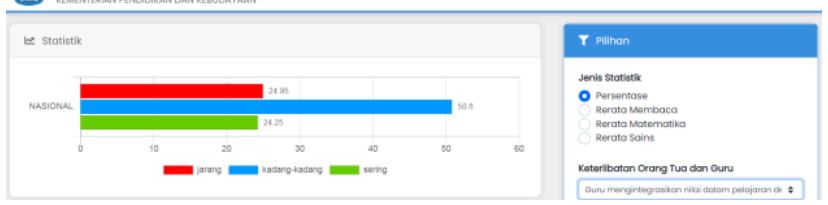

Fig. 5. Percentage of teacher integrating values in lessons with everyday life.

From the figure 5, we get know that as many as 50.8\% of students answered that teachers "sometimes" integrate values in lessons with daily life.

The reading and math means score for the questionnaire were as follows.

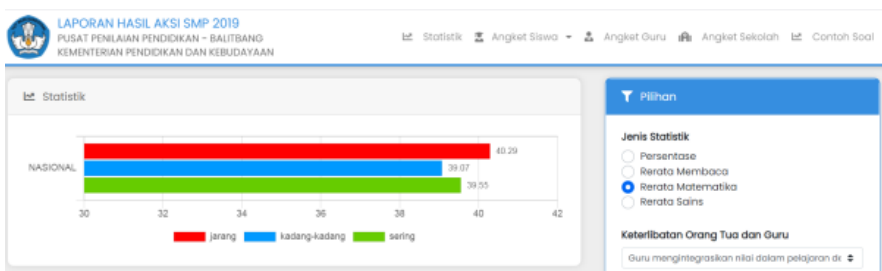

Fig. 6. Student's national mathematics mean score for integrate values in lessons with everyday life.

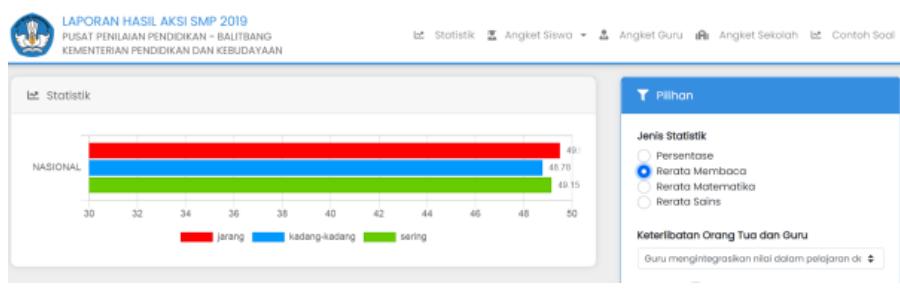

Fig. 7. Student's national reading mean score for integrate values in lessons with everyday life.

The mean score for the two competencies in figure 6 and 7 show the opposite. The mean score was higher for students who answered "rarely" than students who answered "frequently". We can conclude that there is no relationship between teachers integrating values in learning with everyday life on students' abilities. Based on research results [9] that interpreting the value of PKN learning in everyday life ideally can develop the character of students for the better.

- Regarding how teachers integrate values in lessons, how often do things like this happen in your class?

Most of the teachers gave examples of how the topics of one subject relate to other subjects.

(65.37\% often, $5.7 \%$ rarely)

Most of the teachers indicated that every lesson can be used in daily life.

(59.52\% often, $3.49 \%$ rarely)
Most of the teachers explained how the new topic and the previous one were related.

(61.65\% often, $5.14 \%$ rarely)

\section{topic one related to another topic}

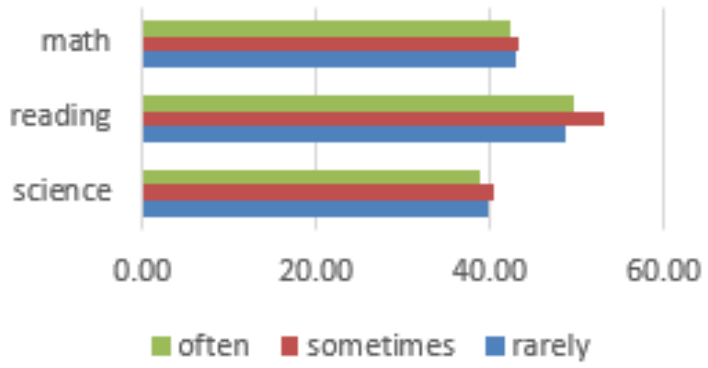

Fig. 8. Student's national mean score based on frequency for relevance of one topic to another.

\section{the teacher indicated that every lesson can be used in daily life.}

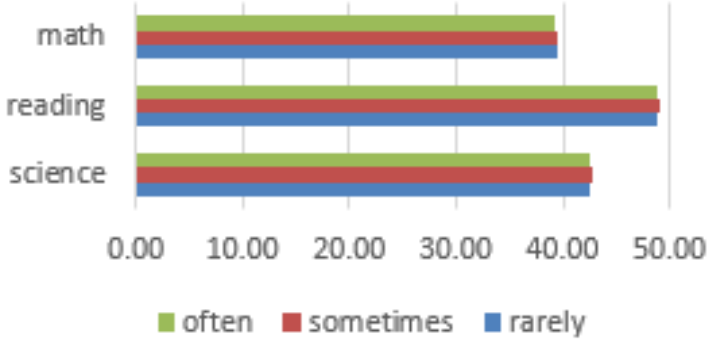

Fig. 9. Student's national mean score based on the frequency for lessons can be used in daily life.

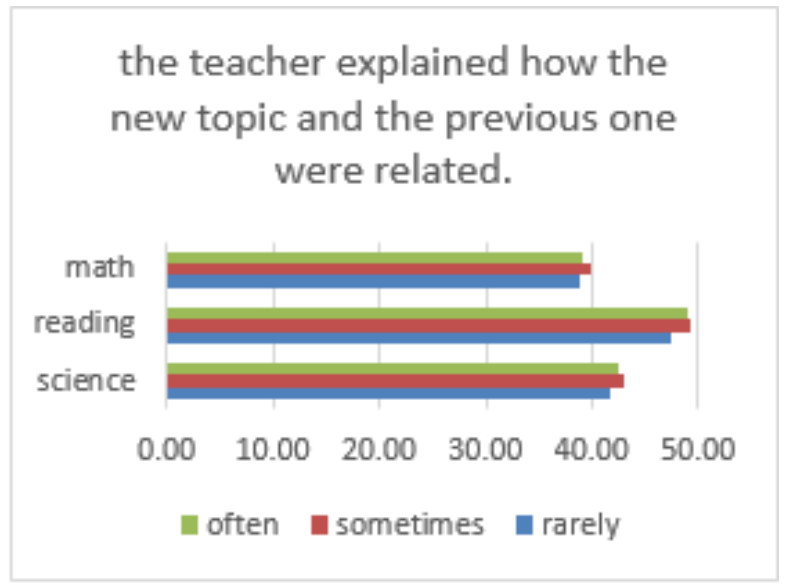

Fig. 10. Student's national mean score based on the frequency for relevance of new topics and previous one. 
More than $60 \%$ of students stated that most teachers almost all the lesson time always give an example how the topic of one subject relates to another, also shows how each lesson can be used in everyday life and how to explain new topics and previous topics to each other related. In other hand, from all three graphs, we can conclude that there is no relationship between the teachers integrate values in lesson with the mean scores (reading,mathematics and sciece).

\section{Using information on the results of assessment and} evaluation to determine learning completeness

- Teachers write general comments (feedback) on each student's assignment
Fig. 14. Student's national science mean score for the feeback from teachers.

The mean scores for the three competencies in the three figure (figure 12-14) show the opposite. The mean scores was higher for students who answered "rarely" than answered "frequently". We can say there is no relationship between the feedback provided by the teacher and student achievements. In contrary, in the study conducted by Cavanaugh [10], it can be conclode that teachers become more aware of the quality of their students by giving feedback on each student's assignment, so that they will be better able to guide them in learning, we can refer to "teaching at the right level" for this task

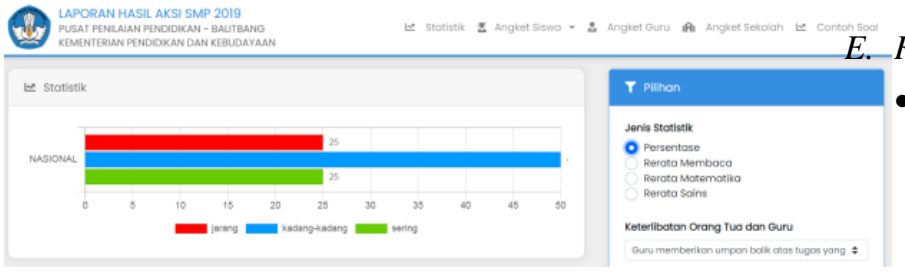

Fig. 11. Percentage of teachers write feedback on each student's assignment.

From figure 11, we know that as many as $49.99 \%$ of students answered that the teacher "sometimes" provides feedback on the work that has been done.

The reading, math, and science means score for the questionnaire were as follows.

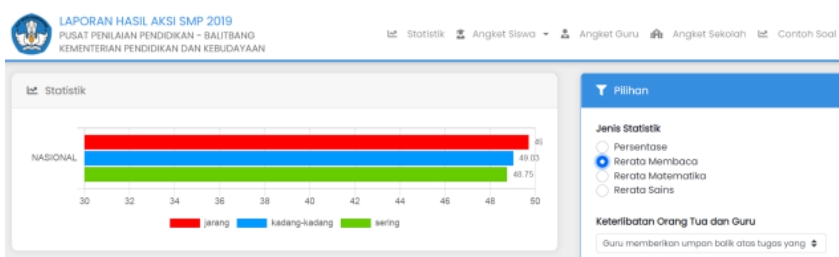

Fig. 12. Student's national reading mean score for the feedback from teachers.

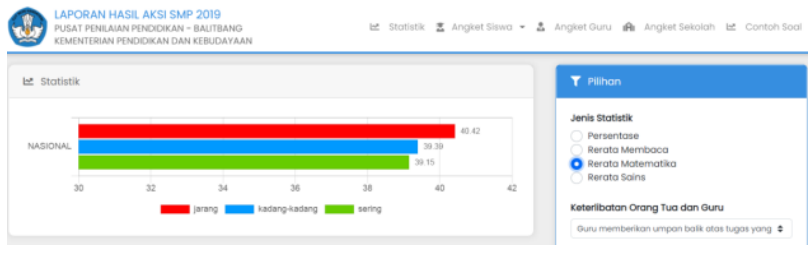

Fig. 13. Student's national mathematics mean score for the feedback from teachers.

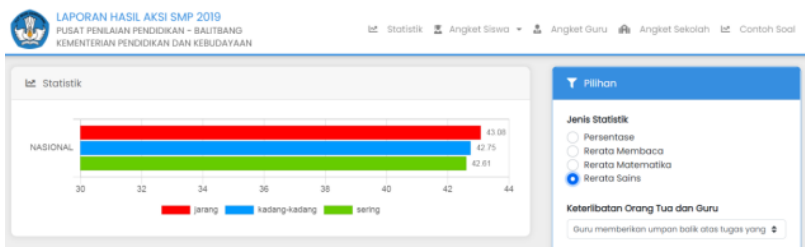

\section{E. Reflecting on the learning that has been implemented}

- Regarding how the teacher gives assignments / homework, how often do things like this happen in your class?

Most teachers encourage students to read text books / packages independently.

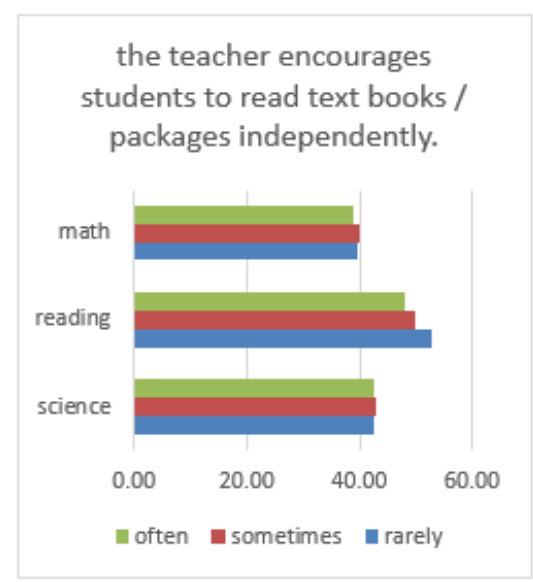

Fig. 15. Stdent's national mean score based on the frequency for the teacher encourages students to read text books independently.

Most teachers encourage students to practice doing the questions a lot.

\section{the teacher encourages \\ students to practice doing a lot of questions}

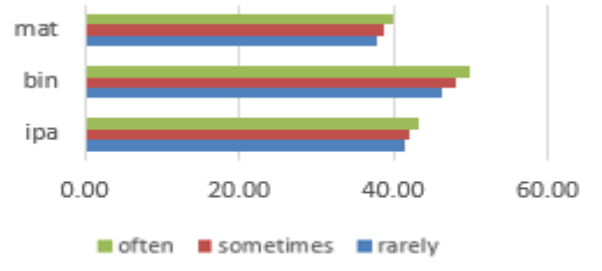


Fig. 16. Student's national mean score based on the frequency for teacher encourages students to practices doing the questions a lot.

From the figure 15 and 16, it can be seen that there is no relationship between teacher recommendations to read text books / packages independently and student achievement. In contrary with the next graph, there is a correlation between the teacher's recommendations for students to practice doing the problems a lot with their score achievements. The more often the students practice doing the questions, the better score they get, especially in reading. We hope this is also correlates with the better students' reading, mathematics and science literacy.

\section{DISCUSSION}

In this study, we found that $21.26 \%$ of teachers often pay attention to their students when they look gloomy. This percentage is small for the elementary and junior high school levels because the students at that age still really need attention from their teachers. In fact, teachers' attention has a significant impact on learning achievement in certain subjects [11]. The attention given by the teacher can be in the form of being wise towards students, assertive but not easily angry, motivating students to learn, being able to stimulate students to be creative, not favoritism, giving orders in a fun way, giving wise admonitions; like giving ideas and input, initiating pedagogical relationships inside and outside the school with students and removing away the violence and intimidation. On the other hand, even though only $21.26 \%$ of teachers who often pay attention to students, but as many as $57.66 \%$ of students still stated that learning with teachers at school is fun. This is a positive thing that must be maintained because it will have an effect on increasing student motivation and learning achievement [12].

In terms of the teacher's respect for students, the student says that most teachers can respect the students and be friendly to students. Both of these attitudes should flourish in education because it affects the character of students. Prophet Muhammad SAW said as narrated by ath-Thabrani, "Give each other gifts so that you love each other." Encouraging with gifts or sweet words, including a form of appreciation. In education, giving awards is one way in the teaching and learning process that is useful to provide motivation for students to encourage them to be more active in learning so that they can achieve learning achievement [13]. Award is a "function of reinforcement" or a function of reinforcement that is more encouraging children to improve their achievements. In addition, $51.84 \%$ the teacher often gives appreciation to students and we can see that the mean score of reading,mathematics and science for students who answered "frequently" was higher than student who answered "rarely or occasionally. It means that the teacher appreciation can affects students' achievement.

The other positive side is teachers are not coming late for class, always present according to their hours and do not play with computers or smartphones in class. This is a good example and professionalism of a teacher. This is the first step in increasing the quantity and quality of teaching and learning activities in the classroom [14]. However, with the busyness that the teacher has, students see that most of their teachers receive calls when teaching more than half of the lesson.

With regard to implementing various approaches, strategies, methods, and learning techniques that educate creatively in the subject being taught. The result of study revealed that as many as $60.16 \%$ of teachers, almost all of the lesson time requires students to make different solutions to a problem in doing assignments and $64.31 \%$ of teachers in almost all lesson times encouraged students to be open to new ideas. This is really importanta for students so that they get used to dealing with problems and finding solutions. In $21^{\text {st }}$ century learning, this method is important so that students are trained in creativity and critical thinking. Giving essay questions during the teaching and learning activities is believed to familiarize students with critical and creative thinking in developing ideas.

In AKSI or PISA we can see that one of the weaknesses of Indonesian students is answering essay questions. This happens because students are not accustomed, so they have difficulty writing down their ideas or understanding in writing. Align with teacher's point of view, according to the results conducted by (Siswono, Abadi, \& Rosyidi (2008) in [15] ) on 130 SD teachers in Sidoarjo Regency shows that teachers have not focused on learning leads to students 'creative thinking abilities, more than $50 \%$ of teachers do not teach students different ways to solve problems, do not try to develop students' imaginations. Similar results are found in research [16] that elementary teacher performances to improve students creative thinking is still weakness. Torrance [17] revealed that teaching for creativity can facilitate children's agency and engagement, such as strategies of learning to learn, or to exploring more new possibilities, often seek to be inventive in order to arouse curiosity and learning motivation. Through teaching creatively, teachers encourage learners' creativity by passing on their enthusiasm, imagination, and other talents [18].

In this study, we also found that $54.48 \%$ of teachers for almost all the lesson time ensure that no one student work imitates other students' work. This is very important for students so that they more independent and foster selfconfidence. Based on research results conducted by Nizar [19] that the habit of imitating other students 'work (cheating) can reduce students' self-efficacy. Nora and Zhang [20] in their study revealed that students with low self-efficacy were more likely to cheat than those who perceived themselves as efficacious. It was further found that peers played a significant role in discouraging cheating by expressing disapproval and informing teachers of dishonest behaviour. In essence, Puspitasari [21] said that every child tends to be independent or has the potential to be independent, because every child is endowed with feelings, thoughts, wills of his own, all of which are psychic totality and different characteristics and structures at each phase of his development. But in fact, the independence of our students is still low during exams, especially the National Examination [22]. 
Another important result from this study are less than 50\% of teachers often encourage students to discuss how to solve a problem, teaching them to defend the answers with relevant evidence and check the accuracy of the information obtained. The three things are important in education and daily life,but in fact, the teacher is not ready for that. Learning to defend the answer with relevant evidence will train the students with scientific opinion and critical thinking. Several studies have developed a program called "problem based learning" [23], [24] and "epistemological understanding" [25] to train argumentation skills which have significant results on the development of the concept of reasoning, critical thinking and student achievement. Even though in other facts, the ability of students to maintain answers by providing relevant evidence is still low [26].

Furthermore, teachers are also still lacking in motivating students not to give up easily in learning. This attitude affects how individuals think, feel, motivate themselves, and act. Students who have high self-efficacy tend to have high selfconfidence and do not give up easily in facing problems. The OECD states that life begins when you are 15 years old. In fact, the authors often find students still giving up easily when working on non-routine questions and if they have to read the stimulus questions which are long and have no effect on their grades in school. This is often the author finds in the AKSI or PISA (Programme for International Students Assessment) survey.

On the other hand, it appears that less than $40 \%$ the teacher is getting used to group discussion and correct errors from tasks that have been done by students. In fact, the habit of group discussion is also an effort to improve student learning outcomes [27]. It is generally assumed that active engagement of students during discussion with peers, some of whom know the correct answer, leads to increased conceptual understanding, resulting in improved performance [28]. Get used to discuss between students in class in line with $21^{\text {st }}$ century competencies, namely ability to work collaboratively (the ability to work together) and the more frequent group discussions students will also train communication skills (ability to communicate) and learn to express arguments (opinions) and defend them with relevant evidence [29].

\section{CONCLUSION}

The results of the study found that students who took the parent teacher support questionnaire in the 2019 AKSI survey thought that their teachers at school had fun teaching them, teachers often appreciate student work, exemplifying how the topic of one subject relates to other subjects, encouraging students to open to new ideas, given the opportunity to express ideas and thoughts. On the other hand, it was also found that teachers were still weak in several pedagogical competencies, namely I terms of motivating students to discuss how to solve a problem, defend answers with evidence, build discussion grup in class, and do not give up easily in learning. In another aspecs, student found that most teacher receive phone calls while teaching.

\section{ACKNOWLEDGMENT}

The authors are grateful to Center of Assessment and Learning Balitbangbuk, Kemendikbud RI for releasing the AKSI 2019 data, so that the data were used for this studi. It can support towards this study. In addition, the authors would like to thank leaders and friends at the Center for Assessment and Learning Balitbangbuk, Kemendikbud RI who have provided input and suggestions, so that this paper is realized.

\section{REFERENCES}

[1] Pusat Asesmen dan Pembelajaran, “Apa Itu AKSI,” 2019.

[2] Pusat Asesmen dan Pembelajaran, "Laporan Hasil AKSI SMP 2019," 2019.

[3] A. Hakim, "Analisis Gambaran Kompetensi Guru terhadap Prestasi Belajar Siswa SMP pada Ujian Nasional Tahun 2015 Provinsi Daerah Istimewa Yogyakarta," Jakarta, 2016.

[4] M. M. Keller, K. Neumann, and H. E. Fischer, "The impact of physics teachers' pedagogical content knowledge and motivation on students' achievement and interest," J. Res. Sci. Teach., vol. 54, no. 5, pp. 586614, 2017, doi: 10.1002/tea.21378

[5] "Standar Kualifikasi Akademik dan Kompetensi Guru," Jakarta, 2007.

[6] T. B. Utiarahman, "Meningkatkan Kompetensi Pedagogik Guru melalui Pelatihan Berjenjang," J. Ilmu Pendidik. Nonform. AKSARA, vol. 05, no. 03, pp. 215-222, 2019.

[7] D. S. S. Santosa and L. Irawati, "Kompetensi Pedagogik Guru Smp Negeri 2 Kaloran Kecamatan Kaloran Kabupaten Temanggung," J. Ecodunamika, vol. 1, no. 2, 2018.

[8] Agusnita, "Kompetensi Pedagogik Guru di SMP Negeri 1 dan 2 Kecamatan Nan Sabaris Kabupaten Padang Pariaman (Studi Komparatif Guru Senior dan Junior)," Bahana Manaj. Pendidik., vol. 3, no. 1, pp. 663-759, 2015.

[9] Z. Ramdani and B. H. Prakoso, "Integritas Akademik: Prediktor Kesejahteraan Siswa di Sekolah,” Indones. J. Educ. Assesment, vol. 2, no. 1, p. 29, 2019, doi: 10.26499/ijea.v2i1.14.

[10] B. Cavanaugh, "Survey of the Literature," Perform. Feed. Teach. Use Praise Oppor. to Respond A Rev. Lit., vol. 36, no. 1, pp. 111-136, 2013 , doi: 10.1353/etc.2013.0001

[11] S. Winarni, "Pengaruh Perhatian Guru, Motivasi Belajar, Dan Kecerdasan Emosional Terhadap Prestasi Belajar Biologi Siswa SMA Negeri 2 Bantul,” vol. III, pp. 81-87, 2015.

[12] D. A. V. Ghasya, "Gerakan Sekolah Menyenangkan dan Ramah Anak (GSMRA) sebagai Wujud Rekonstruksi Pelaksanaan Pendidikan pada Jenjang Sekolah Dasar," Pros. Semin. Nas. Pendidik. Dasar 2018, pp. 227-236, 2018

[13] R. P. Hapsari, "Studi Tentang Pelaksanaan Pemberian Reward Dalam Meningkatkan Motivasi Belajar Kelompok-a Di Tk Islam Al-Azhar 35 Surabaya Study Councering the Implemetation of Reward in Increasing Motivation for Learning Group-a in Al-Azhar 35 Islamic Kindergarten 35 Su,” J. BK Unesa, vol. 04, no. 01, pp. 274-284, 2013.

[14] S. Bariroh, "Analisis Pengaruh Kedisiplinan Kerja Guru Terhadap Prestasi Belajar Siswa Pada SMA Negeri 1 Bumiayu Kabubapaten Brebes," J. Kependidikan, vol. 3, no. 9, pp. 33-51, 2015

[15] I. K. Tatag Yuli Siswanto, Abdul Haris Rosyidi, Yuliani Puji Astuti, "Pemberdayaan Guru Dalam Pembelajaran Matematika Untuk Meningkatkan Kemampuan Berpikir Kreatif Siswa Sd," J. Ilmu Pendidik., no. 2, p. 211, 2012.

[16] T. Yuli, "Developing Teacher Performances to improving Students Creative Thinking Capabilities In Mathematics," no. May, pp. 18-20, 2014.

[17] E. Paul Torrance, Education and the creative potential. 1963.

[18] B. Lucas, Creative teaching, teaching creativity and creative learning. London: Continuum, 2001. 
[19] M. Nizaar, "Perilaku Mencontek Sebagai Indikasi Gagalnya Efikasi Diri (Self Efficacy) Anak Dalam Pembelajaran," TAMAN CENDEKIA J. Pendidik. Ke-SD-an, vol. 1, no. 1, p. 27, 2017, doi: 10.30738/tc.v1i1.1577.

[20] W. L. Y. Nora and K. C. Zhang, "Motives of cheating among secondary students: The role of self-efficacy and peer influence," Asia Pacific Educ. Rev., vol. 11, no. 4, pp. 573-584, 2010, doi: 10.1007/s12564-0109104-2.

[21] R. Puspitasari, "Pengaruh Pemberian Hadiah ( Reward ) Terhadap Kemandirian Belajar Anak Di Tk Tunas Muda Karas Kabupaten Magetan TA 2015/2016," no. 21 November 2015, pp. 53-55, 2016

[22] F. Rohma, "Cheating on Nasional Exam in Senior High School," Artik. Ilm. Has. Penelit. Mhs., 2013.

[23] H. P. Agusni and A. Wahyudi, "Pengaruh Skill Argumentasi Menggunakan Model Problem Based Learning Terhadap Hasil Belajar Siswa," Ekp, vol. 126, no. 3, p. 14, 2011.

[24] R. W. Akhdinirwanto, R. Agustini, and B. Jatmiko, "Problem-based learning with argumentation as a hypothetical model to increase the critical thinking skills for junior high school students," J. Pendidik. IPA
Indones. vol. 9, no. 3, pp. 340-350, 2020, doi: 10.15294/jpii.v9i3.19282.

[25] L. Mason and F. Scirica, "Prediction of students' argumentation skills about controversial topics by epistemological understanding," Learn. Instr., vol. 16, no. 5, pp. 492-509, 2006, doi: 10.1016/j.learninstruc.2006.09.007.

[26] S. P. Liestari and M. Muhardis, "Kemampuan Literasi Membaca Siswa Indonesia (Berdasarkan hasil UN dan PISA)," Indones. J. Educ Assesment, vol. 3, no. 1, p. 24, 2020, doi: 10.26499/ijea.v3i1.53.

[27] D. Vinsensia, "Upaya peningkatan hasil belajar dengan teknik diskusi kelompok pada pokok bahasan bilangan bulat dan pola bilangan oleh siswa SMP Negeri 1 Tanjung Pura Kab. Langkat," J. Matik Penusa, vol 19 (1), no. 1, p. 2016, 2016

[28] M. Smith, W. Wood, W. Adams, C. Wieman, and J. K. Knight, "Why Peer discussion improves Student Performance on In-Class Concept Questions," Trans. Am. Ophthalmol. Soc., vol. 106, no. January, pp. 9092, 2008.

[29] L. C. Larson and T. N. Miller, "21st Century Skills: Prepare Students for the Future," Kappa Delta Pi Rec., vol. 47, no. 3, pp. 121-123, 2011, doi: $10.1080 / 00228958.2011 .10516575$. 